\title{
The Traffic Impact Analysis on Province Roads as Requirement for Licensing Services Provision in Building Sector
}

\author{
Bambang Mursito*), Sri Kusriyah"*) and Jawade Hafidz ${ }^{* * *}$ \\ *) Central Java Provincial Transportation department email bam_sit@yahoo.co.id \\ ${ }^{* *}$ F Faculty of Law, Universitas Islam Sultan Agung (UNISSULA) Semarang \\ **) Faculty of Law, Universitas Islam Sultan Agung (UNISSULA) Semarang
}

\begin{abstract}
.
The purpose of this research is to study and analyze the impact of traffic on provincial roads as a permit requirement in the building sector by local governments based in Central Java and the solution efforts. The approach method used in this research is sociological juridical. The results of the study indicate that: the implementation of the traffic impact analysis on provincial roads encountered obstacles, among others, before the implementation of the traffic impact analysis, difficulties were the preparation of the required documents for the implementation of the traffic impact analysis, and in the implementation of the traffic impact analysis, including those related to supervision issues, not guided by the authority to analyze traffic impacts based on road status, do not understand the laws and regulations and related provisions, and lack of law enforcement.
\end{abstract}

Keywords: Building; Impact; Licensing; Provincial; Road; Traffic.

\section{Introduction}

The building is one of the physical forms of space utilization. Therefore, in the regulation of buildings, it still refers to spatial planning regulations in accordance with applicable laws and regulations. To ensure legal certainty and order in the administration of buildings in Indonesia, every building must be organized in an orderly manner, realized according to its function, and fulfilled building maintenance requirements. ${ }^{1}$

In Article 8 of Act No. 28 of 2002 concerning Buildings, the administrative requirements of buildings are determined, namely: Status of land rights and/or utilization permits from land rights holders; Building ownership status;Permit to construct a building; and Ownership, and building data collection.

Arrangements for granting permits for the establishment and use of buildings are carried out to ensure that the physical growth of the city in order to support overall economic growth does not cause damage to the physical arrangement of the city. The function of the building as a place for economic, cultural, social, and educational activities is related to the function of the local government as an agent of development, agent of change, and agent of regulation. ${ }^{2}$

In such a function, local governments have an interest in building permits. Building permits are enforced so that there is no chaos in urban spatial planning,

\footnotetext{
${ }^{1}$ Act No. 28 of 2002 concerning Buildings, Article 5

${ }^{2}$ Adrian Sutedi, Hukum Perizinan Dalam Sektor Pelayanan Publik, First Edition, Third Printing, Sinar Grafika, Jakarta, 2015, p. 222.
} 
and is a form of controlling the use of urban space which will have a development impact.

In general, a permit application must go through certain procedures determined by the government, as the licensee. In addition to having to go through certain procedures, the permit applicant must also meet certain requirements that are determined unilaterally by the government or the licensor. The licensing procedures and requirements depend on the type of permit, the purpose of the permit, and the agency granting the permit. Requirements are things that must be met by the applicant to obtain the requested permit. The licensing requirements are in the form of complete documents or letters.

Talking about the impact of building construction, such as in real estate, industrial estate, shopping centers, and so on, currently it is very necessary to regulate the impact of development control, which includes environmental impacts, impact fees, and traffic impact assessments ${ }^{3}$. Development always has an environmental impact. Differences in perception between the government and the community on land management. The government tries to coerce the people, while the people try to fight the government. This situation can lead to vertical conflict, between the government and the community. ${ }^{4}$

One of the impacts of building construction is a traffic impact assessment. The traffic impact assessment is an obligation that must be fulfilled by the developer to conduct an analytical study of the traffic impact. The study should be able to describe the performance of the road network before and after construction and the impacts it causes, then how to find solutions to overcome them. ${ }^{5}$

In terms of the impact of traffic on building construction, the local government plays a role in fostering building management, both for building owners, building users, construction service providers, and the public with an interest in realizing orderly operation and building reliability that meets administrative and regulatory requirements technical aspects, as well as those implemented by strengthening the capacity of effective administration based on good governance.

The fact that we can now see the increasing number of towering buildings and various forms of buildings as well as the increasing use of modern tools and others will cause problems both now and in the future if they are not balanced with regulations and the ability to implement them. ${ }^{6}$

The implementation of regulation, empowerment, and supervision of the administration of buildings in the regions is based on laws and regulations

\footnotetext{
${ }^{3}$ Ong Argo Victoria, Ade Riusma Ariyana. 2020. "Policy Analysis Study Of The Traffic Accident Of Criminal System Which Make Loss Of Life", International Journal of Law Reconstruction, Vol. 4 No. 2, p. 136-144, http://jurnal.unissula.ac.id/index.php/lawreconstruction/article/view/11382

${ }^{4}$ Suroto and Gunarto, "Dampak Penambangan Pasir Besi Di Desa Bandungharjo, Banyumanis Dan Ujungwatu Kabupaten Jepara Menurut UU No. 32 Tahun 2009 Tentang Perlindungan Dan Pengelolaan Lingkungan Hidup". Jurnal Daulat Hukum Vol. 1. No. 1 March 2018, p. 257, http://jurnal.unissula.ac.id/index.php/RH/article/view/2644/1988

5Ibid., p. 222.

${ }^{6}$ Elsi Kartika Sari, "Tinjauan Yuridis Terhadap Pengaturan Hukum Bangunan Di Indonesia, Hukum Pidana dan Pembaruan Hukum", https://trijurnal.lemlit.trisakti.ac.id/hpph/article/download/3577/3032
} 
concerning regional government, one of which is the Central Java Provincial Regulation Number 1 of 2020 concerning the Implementation of Transportation.

Constructing a building with the provisions required by the legislation must pay attention to the traffic impact analysis as a requirement to obtain a building construction permit. This is as stated in Article 45 Regional Regulation of Central Java Province Number 1 of 2020 that: The result of the traffic impact analysis as referred to in Article 44 paragraph (1) is one of the requirements for the developer or builder to obtain:

- location permission;

- building permit; or

- building construction permit with a special function in accordance with the laws and regulations in the field of building.

To obtain a permit, in this case a permit as stipulated in Article 45 of the Central Java Provincial Regulation Number 1 of 2020 as a form of licensing requirements from the local government to the public.

Licensing requirements in the development era are very important so that a person or legal entity can have rights and obligations that enable him to enjoy and benefit from his business then the plan for a development must obtain a building permit, as stipulated in Regional Regulation Number 1 of 2020, it is required for the developer or builder to carry out a traffic impact analysis.

Traffic regulation is an important thing for people's lives. Improving traffic safety and road transportation is needed so that people can carry out all their activities properly, smoothly, safely, and comfortably, so that the products produced can continue to grow and develop. ${ }^{7}$

The development in the center of activity, settlements, and infrastructure will have an impact due to changes in land use where buildings result in changes in the system of transportation. Therefore, to carry out the construction of activities, settlements, and infrastructure in the Central Java Province, it is necessary to analyze the impact of traffic (andalalin) in order to anticipate the emergence of disturbances in security, safety, order, and smooth traffic and road transportation, along with the growth of vehicles in the province of Central Java which continues to increase.

Traffic impact analysis approval must be owned by the land owner before applying for a location permit, building permit or building construction permit with a special function of a construction activity, settlement, and infrastructure, the land owner should also pay attention to the impact on the environment, for example buildings on the side of the road which must have its own parking area or land according to capacity, so as not to create congestion due to the impact of parking on the shoulder of the road.

Regarding the implementation of traffic impact analysis on provincial roads in accordance with Regional Regulation No. 1 of 2020, the implementation of traffic impact analysis on provincial roads is the authority of the governor who is assisted by a technical team, but in the implementation of traffic impact analysis on

${ }^{7}$ Lukman Hakim, "Tinjauan Hukum Terhadap Pelanggaran Kelebihan Muatan Di Jembatan Timbang Kabupaten Blora", International Journal of Law Society Services, Volume 1 No. 1 March 2021, p. 31. http://jurnal.unissula.ac.id/index.php/ijls/article/view/14739/5338 
provincial roads so far this has not been done optimally, this can be seen from the lack of requests for analysis of the impact of traffic on provincial roads at the Transportation Service of Central Java Province.

The role of the Department of Transportation is very important, in terms of carrying out traffic impact analysis on any plans for the development of activity centers, settlements, and infrastructure that will cause disturbances in security, safety, order and smooth traffic and road transportation on provincial roads, which will be the result of the analysis traffic impacts are used by land owners or builders to obtain building permits.

At a number of points in the area, the construction of buildings such as offices, malls, and others without considering the traffic impact analysis. One example is the Majapahit Transmart shopping activity on St. Brigjend Sudiarto No. 761, Plamongansari, Semarang which is the main shopping and tourist destination in the Majapahit area and its surroundings. With these shopping activities, it will cause a traffic pull on the road around St. Majapahit and its surroundings and will increase the volume of traffic. Although it is not the only cause of the decline in road performance, the increase in road traffic volume will result in traffic jams on the roads around shopping centers. This is often caused by human behavior that does not obey traffic signs and the movement of vehicles in and out of shopping centers and vehicles crossing the road, both aiming to enter the shopping center and those intending to leave the shopping center. This condition should be anticipated if from the beginning of its establishment the land owners have a traffic impact analysis, so that traffic problems can be identified as early as possible.

The construction of the building, both during construction and its use for offices and trade, will certainly increase the traffic flow in the vicinity, and can result in congestion. On site activity of trade and services in the area resulted in increased activity of road users, the emergence of traffic generation and high side barriers, where at certain hours traffic jams and delays often occur. ${ }^{8}$ According to MN Nasution, the progress of transportation is the result of the human need to travel to other places to find the goods needed or carry out activities, and send goods to other places that need these goods. ${ }^{9}$

Based on the description that has been stated above, the purpose of this study is to study and analyze the impact of traffic on provincial roads as a permit requirement in the building sector by local governments based in Central Java and its settlement efforts.

\section{Research Methods}

The approach method used in this research is the sociological juridical method. This research is more specific by conducting descriptive analysis research.

\footnotetext{
${ }^{8}$ Iwan Wijanarko and Mohammad Agung Ridlo, "Faktor-Faktor Pendorong Penyebab Terjadinya Kemacetan Studi Kasus : Kawasan Sukun Banyumanik Kota Semarang”, Jurnal Planologi Vol. 14, No. 1, April 2017, p. 63,http://jurnal.unissula.ac.id/index.php/psa/article/view/3859/2764

${ }_{9}^{9}$ Meta Suryani and Anis Mashdurohatun, "Penegakan Hukum Terhadap Eksistensi Becak Bermotor Umum (Bentor) Berdasarkan Undang-Undang Nomor 22 Tahun 2009 Tentang Lalu Lintas Dan Angkutan Jalan", Jurnal Pembaharuan Hukum Vol 3, No 1 (2016), p. 22. http://journal.unissula.ac.id/index.php/PH/article/view/1341/1035
} 
The data used in this study are primary data and secondary data. The data collection method used is literature study and interviews, in order to obtain primary data and secondary data related to research problems. The sampling was done by purposive sampling method. Data analysis used in this research is qualitative analysis.

\section{Results and Discussion}

\subsection{Provide Facilities for the Movement of Passengers}

In the transportation system, the purpose of planning is to provide facilities for the movement of passengers/goods from one place to another or from various land uses. Whereas in the land development system, the purpose of planning is to achieve the function of the building and must be profitable. Judging from the two goals often lead to conflict. This is the fundamental assumption of the traffic impact analysis to bridge the two objectives above, or in other words the process of transportation planning and land development are tied to each other.

Land development will not occur without a transportation system, while a transportation system cannot be provided if it does not serve economic interests or development activities. The construction of a new area or building will have a direct impact on traffic around the area. For this reason, historical traffic data is needed which is used as a basis for determining the influence of the new area on the surrounding roads.

Traffic impact analysis will be used to estimate future traffic conditions, both for conditions without "regional development" or "with regional development". Traffic impact analysis is a special study that assesses the effects of traffic generated by an area development on the surrounding transportation network.

Analysis of the impact of traffic on provincial roads is basically an effort so that the construction of activity centers, settlements, and infrastructure does not cause disturbances to security, safety, order and smooth traffic and road transportation related to the implementation of transportation on provincial roads. ${ }^{10}$

The obstacles before carrying out the traffic impact analysis, namely complaints from the founders or builders in the preparation of the requirements document for the implementation of the traffic impact analysis. For the founders or builders, the traffic impact analysis document is considered to lengthen the licensing bureaucracy. The traffic impact analysis document is not integrated with the environmental impact analysis document, so the applicant has the obligation to make two documents, namely a traffic impact analysis document and an environmental impact analysis document. ${ }^{11}$

However, there are several obstacles in carrying out the analysis the impact of traffic on provincial roads carried out by the Central Java Provincial Government, especially the Department of Transportation which handles traffic impact analysis, including: 12

\footnotetext{
10 Interview with Adhi Dwi Nugroho, A.Md.LLAJ, SE, MT, as Head of Road Traffic Management Section, on 27 September 2021.

11 Ibid.

12 Ibid.
} 
- Less than optimal in supervising the implementation of traffic impact analysis which includes pre-development and post-construction;

- District/City Governments, especially the Transportation Service/Office in carrying out traffic impact analysis, are often not guided by the authority to analyze traffic impacts based on road status;

- Regency/City Regional Apparatus Organizations that handle building permits do not understand the relevant laws and regulations, so they continue to process applications for Building Construction Permits and building construction permits with special functions in accordance with statutory regulations in the building sector.;

- Lack of law enforcement on the Central Java Provincial Regulation Number 1 of 2020 concerning the Implementation of Transportation, especially in Article 44 paragraph (1).

It can be concluded that the obstacles prior to the implementation of the traffic impact analysis were the difficulties experienced by the founders or builders in fulfilling the required documents for the implementation of the traffic impact analysis. Meanwhile, obstacles in carrying out traffic impact analysis on provincial roads include lack of supervision, traffic impact analysis not guided by the authority to analyze traffic impacts based on road status, lack of understanding of laws and regulations and related provisions, and lack of law enforcement on regional regulations. Central Java Province Number 1 of 2020.

\subsection{Efforts to resolve obstacles in the implementation of traffic impact analysis on provincial roads.}

Along with the passage of time, urban development and land use are always evolving and changing according to the needs and policies of decision makers, both within the local government and the central government. One of the developments of land use in urban areas is the change in the designation of the area which has turned into activity centers. Both activity centers that are commercial services and activity centers that are service to the community. ${ }^{13}$

The construction of a primary activity center in an urban area will be able to change the structure of urban space in the area where the activity center development is carried out. Changes in the structure of urban space will affect the pattern of movement which in turn will burden the existing road network in an area. ${ }^{14}$

Each activity and/or business development plan in an area will have an impact on the surrounding area, including its impact on road traffic. The impact of road traffic needs to be anticipated and handled appropriately according to the location, type, and scale of the impact it will cause.

\footnotetext{
${ }^{13}$ Departemen Perhubungan, Direktorat Jenderal Perhubungan Darat, Direktorat Bina Sistem Transportasi Perkotaan, Satuan Kerja Pengembangan Sistem Transportasi Ramah Lingkungan dan Andhika Angkayasa Konsultan, Laporan Akhir, Perencanaan Teknis Dampak Lalu Lintas Pembangunan Pusat Kegiatan Pada Ruas Jalan Nasional Di Wilayah Perkotaan, Departemen Perhubungan dan Andhika Angkayasa Konsultan, Jakarta, 2009, p. 1-3.

14 Ibid
} 
Traffic impact analysis study is a study that includes a study of the road network affected by regional development, over a certain radius. The obligation to conduct a traffic impact analysis study depends on the traffic generation caused by the development of the area. The amount of traffic generation rate is determined by the type and amount of land use.

How many types of land uses/areas are in the process of development, it is necessary to conduct a traffic impact analysis study, including among others: ${ }^{15}$

- Settlements;

- Apartments;

- Office and/or trade center;

- Office/government center;

- Shopping center;

- Supermarkets/supermarkets;

- Hotels;

- Hospital;

- University/school;

- Industrial area;

- Restaurants;

- Terminals;

- Port/Airport;

- Stadium;

- Places of worship.

However, in the implementation of traffic impact analysis on provincial roads, there are still obstacles experienced by the Department of Transportation, which handles traffic impact analysis, which is related to the authority to carry out traffic impact analysis, supervision of the implementation of traffic impact analysis, understanding of laws and regulations invitation, and law enforcement. 16

The efforts to resolve the obstacles before and during the implementation of the traffic impact analysis on provincial roads, among others: ${ }^{17}$

1. Prior to the traffic impact analysis:

The traffic impact analysis document can be integrated with the environmental impact analysis document into one document.

2. Implementation of traffic impact analysis:

- It is necessary to have the authority of the evaluation team in terms of the authority to take persuasive, curative and repressive actions;

- The need for budgeting costs in the Regional Revenue and Expenditure Budget to support the activities of the evaluation team for the results of the traffic impact analysis as mandated in Article 15 of the Regulation of the Minister of Transportation Number 75 of 2015 concerning the Implementation of Traffic Impact Analysis;

- In granting the approval of the results of the traffic impact analysis, it is necessary to incur a fee as non-tax state revenue in accordance with applicable

\footnotetext{
15Ibid., p. 5-3.

${ }^{16}$ Interview with Adhi Dwi Nugroho, Op.Cit

17 Ibid.
} 
regulations and be included in regional regulations as mandated in Article 13 paragraph (5) of the Regulation of the Minister of Transportation Number 75 of 2015;

- Conduct socialization related to the authority of traffic impact analysis based on road status (national, provincial, and district/city) to districts/cities, especially to OPD (Regional Apparatus Organizations) which handle traffic impact analysis, and governors need to make Circulars to districts/cities to comply with Law 22 of 2009 concerning Road Traffic and Transportation, Government Regulation Number 32 of 2011 concerning Management and Engineering, Impact Analysis, and Management of Traffic and Road Transportation Needs, Regulation of the Minister of Transportation Number 75 of 2015 concerning Implementation of Traffic Impact Analysis Traffic, and Central Java Province Regional Regulation Number 1 of 2020 concerning the Implementation of Transportation;

- It is necessary to understand the abuse of authority (Freis Ermessen) in the licensing process and the effects arising from a licensing product that exceeds its authority;

- Conduct socialization to Regency/City Regional Apparatus Organizations that handle permits in the building sector so that in the process of applying for building permits they understand the laws and regulations regarding what documents must be in place, before applying for Building Permits and building construction permits with special functions;

- Firmness is needed for the apparatus in charge of enforcing regional regulations (Pamong Praja Police Unit) against violations of Article 44 paragraph (1), in the form of administrative sanctions which include written warnings, administrative fines, suspension of permits, and/or revocation of permits.

It can be concluded that efforts to resolve problems before carrying out a traffic impact analysis, namely a traffic impact analysis document can be integrated with an environmental impact analysis document into one document. For efforts to resolve the obstacles to the implementation of the traffic impact analysis, it can be mentioned, among others, the need for the authority of the evaluation team to take persuasive, curative, and repressive actions; the need for budgeting costs in the Regional Revenue and Expenditure Budget to support the activities of the evaluation team for the results of the traffic impact analysis; need to be charged a fee in granting approval of traffic impact analysis results; conduct socialization related to traffic impact analysis authority based on road status; it is necessary to understand the abuse of authority in the licensing process; conduct socialization to Regional Apparatus Organizations that handle permits in the building sector; and the need for firmness of the apparatus in charge of enforcing regional regulations.

\section{Clossing}

The results of the study indicate that: the implementation of the traffic impact analysis on provincial roads encountered obstacles, among others, before the implementation of the traffic impact analysis, difficulties were the preparation of the required documents for the implementation of the traffic impact analysis, and in the implementation of the traffic impact analysis, including those related to supervision 
issues, not guided by the authority to analyze traffic impacts based on road status, do not understand the laws and regulations and related provisions, and lack of law enforcement; Efforts to resolve the obstacles before carrying out the traffic impact analysis on provincial roads, namely the traffic impact analysis document can be integrated with the environmental impact analysis document into one document.

\section{References}

\section{Journals}

[1] Elsi Kartika Sari, "Tinjauan Yuridis Terhadap Pengaturan Hukum Bangunan Di Indonesia, Hukum Pidana dan Pembaruan Hukum", https://trijurnal.lemlit.trisakti.ac.id/hpph/article/download/3577/3032

[2] Iwan Wijanarko and Mohammad Agung Ridlo, "Faktor-Faktor Pendorong Penyebab Terjadinya Kemacetan Studi Kasus : Kawasan Sukun Banyumanik Kota Semarang", Jurnal Planologi Vol. 14, No. 1, April 2017, p. 63, http://jurnal.unissula.ac.id/index.php/psa/article/view/3859/2764

[3] Lukman Hakim, "Tinjauan Hukum Terhadap Pelanggaran Kelebihan Muatan Di Jembatan Timbang Kabupaten Blora", International Journal of Law Society Services, Volume 1 No. 1 March 2021, p. 31. http://jurnal.unissula.ac.id/index.php/ijls/article/view/14739/5338

[4] Meta Suryani and Anis Mashdurohatun, "Penegakan Hukum Terhadap Eksistensi Becak Bermotor Umum (Bentor) Berdasarkan Undang-Undang Nomor 22 Tahun 2009 Tentang Lalu Lintas Dan Angkutan Jalan", Jurnal Pembaharuan Hukum Vol 3, No 1 (2016), p. 22. http://jurnal.unissula.ac.id/index.php/PH/article/view/1341/1035

[5] Ong Argo Victoria, Ade Riusma Ariyana. 2020. "Policy Analysis Study Of The Traffic Accident of Criminal System Which Make Loss Of Life", International Journal of Law Reconstruction, Vol. 4 No. 2, p. 136-144, http://jurnal.unissula.ac.id/index.php/lawreconstruction/article/view/1138 $\underline{2}$

[6] Suroto and Gunarto, "Dampak Penambangan Pasir Besi Di Desa Bandungharjo, Banyumanis Dan Ujungwatu Kabupaten Jepara Menurut UU No. 32 Tahun 2009 Tentang Perlindungan Dan Pengelolaan Lingkungan Hidup". Jurnal Daulat Hukum Vol. 1. No. 1 March 2018, , http://jurnal.unissula.ac.id/index.php/RH/article/view/2644/1988

\section{Books}

[1] Adrian Sutedi, Hukum Perizinan Dalam Sektor Pelayanan Publik, First Edition, Third Printing, Sinar Grafika, Jakarta, 2015

[2] Departemen Perhubungan, Direktorat Jenderal Perhubungan Darat, Direktorat Bina Sistem Transportasi Perkotaan, Satuan Kerja Pengembangan Sistem Transportasi Ramah Lingkungan dan Andhika Angkayasa Konsultan, Laporan Akhir, Perencanaan Teknis Dampak Lalu Lintas Pembangunan Pusat Kegiatan Pada Ruas Jalan Nasional Di Wilayah Perkotaan, Departemen Perhubungan dan Andhika Angkayasa Konsultan, Jakarta, 2009 


\section{Interview}

[1] Interview with Adhi Dwi Nugroho, A.Md.LLAJ, SE, MT, as Head of Road Traffic Management Section, on 27 September 2021. 